\title{
Improving vitamin $D$ status in bariatric surgery subjects with monthly high-dose ergocalciferol
}

A randomized clinical trial

\author{
Shannon Galyean ${ }^{1}$ (D), David Syn², Hadil S Subih³ ${ }^{3}$ and Mallory Boylan ${ }^{1}$ \\ Department of Nutritional Sciences, Texas Tech University, Lubbock, TX, USA \\ 2 Department of Surgery Advanced Bariatric Surgery Center, Lubbock, TX, USA \\ 3 Department of Nutrition and Food Technology, Faculty of Agriculture, Jordan University of Science and Technology, \\ Irbid, Jordan
}

\begin{abstract}
Background: Vitamin D insufficiency is common before and after bariatric surgery. Optimal supplementation to treat vitamin D insufficiency is not clearly defined. Objective: Determine if serum $25(\mathrm{OH}) \mathrm{D}$ levels improve by the consumption of an additional monthly ergocalciferol supplement by subjects after bariatric surgery. Study design: Thirty-two subjects were randomly divided to receive an additional $100,000$ IUs of ergocalciferol monthly after bariatric surgery $(n=10)$ or standard level vitamin $D$ supplement after bariatric surgery ( $n=22)$. Serum $25(\mathrm{OH}) \mathrm{D}$, calcium, and hemoglobin A1c levels were measured preoperatively and one year after bariatric surgery. Results: Mean changes in BMI at 1-year post-operation was $-18.12 \pm 6.46 \mathrm{~kg} / \mathrm{m}^{2}$ in the control group versus $-18.84 \pm 4.7 \mathrm{~kg} / \mathrm{m}^{2} ; p=0.638$ in the vitamin D group. One year after bariatric surgery, the mean changes from baseline in vitamin D levels were $2.69 \pm 9.4$ and $12.4 \pm 17.0 \mathrm{ng} / \mathrm{mL}$ in control and intervention groups, respectively. The treated group showed a marginally higher mean increase in Vitamin $D$ than the control group, $p=0.059$. Other mean changes at 1 -year post-surgery that were not significantly different include calcium $-0.264 \pm 0.45$ and $-0.21 \pm 0.509 \mathrm{mg} / \mathrm{dl}$ in control and intervention groups, respectively and $\mathrm{HbA}_{1 \mathrm{c}}-1.0 \pm 1.21$ and $-0.95 \pm 0.071 \%$ in control and intervention groups, respectively. Conclusion: This study showed 100,000 IUs ergocalciferol once a month is a safe and effective treatment for vitamin D insufficiency in most patients having bariatric surgery.
\end{abstract}

Keywords: Bariatric surgery, Ergocalciferol, vitamin D, supplement, deficiency

\section{Introduction}

Vitamin D deficiency is prevalent among populations with severe obesity and those having bariatric surgery. In fact, approximately $40-80 \%$ of patients with severe obesity have been documented as having inadequate vitamin $\mathrm{D}$ status, a serum $25(\mathrm{OH}) \mathrm{D}$ level of $<50 \mathrm{nmol} / \mathrm{L}(20 \mathrm{ng} / \mathrm{mL})$ preoperatively [1-4]. The definition of vitamin $\mathrm{D}$ insufficiency is serum $25(\mathrm{OH}) \mathrm{D}$ between $30-50 \mathrm{nmol} / \mathrm{L}(12-20 \mathrm{ng} / \mathrm{mL})$ and vitamin D deficiency is serum $25(\mathrm{OH}) \mathrm{D}<30 \mathrm{nmol} / \mathrm{L}$ $(<12 \mathrm{ng} / \mathrm{mL})$ [1].

Evidence suggests that obesity on its own is a risk factor for vitamin D deficiency. Current research also suggests that low $25(\mathrm{OH})$ D status in patients with severe obesity has an inverse association with $25(\mathrm{OH}) \mathrm{D}$, body weight and adiposity, adding to the growing evidence for a higher vitamin D requirement in obesity patients [5-9]. The exact mechanism for vitamin D deficiency in severe obesity is not known. Some researchers suggest the cause as the increased sequestration of vitamin $\mathrm{D}$ in adipose tissue, resulting in a decrease in bioavailability [10-13].

The rate of obesity in America has doubled from 15\% to more than $30 \%$ over the past 25 years and affected about 93.3 million of US adults in 2015-2016 [14]. As the prevalence of obesity increases, the number of bariatric procedures in America continues to rise [15]. The Roux-en-Y gastric bypass procedure combines both a restrictive and malabsorptive state for weight reduction. The biliopancreatic diversion with duodenal switch is a procedure with an even greater degree of malabsorption [16]. As a result, postoperative intestinal malabsorption of calcium and vitamin $\mathrm{D}$ has been documented [17-19]. The principal site for active calcium absorption is the duodenum and proximal ileum, while vitamin D absorption takes place primarily in the jejunum and ileum. The biliopancreatic diversion with duodenal switch involves bypassing $60 \%$ of the intestines and fat-soluble vitamin absorption is affected [16, 20-22]. Even though gastric bypass does not affect 
the sites of vitamin D absorption, it is suggested that Roux-en-Y anastomosis decreases absorption of fat-soluble vitamins due to poor mixing with the bile salts and exclusion of the duodenum and proximal jejunum $[15,23,24]$. After bariatric surgery, absorption is compromised, dietary intake is reduced, and supplements are usually required to maintain adequate serum levels of vitamin D [10, 25-27]. Research has shown that more than $50 \%$ of bariatric surgery patients can experience vitamin D deficiency [28-31]. A meta-analysis of 51 studies that reviewed 25-hydroxyvitamin D [25(OH)D] status pre and post bariatric surgery, identified 17 of these studies that showed mean 25(OH)D levels $\leq 20 \mathrm{ng} / \mathrm{ml}[27,32]$. Bariatric surgery patients may also face a double threat to their bone health [33-37]. Even when taking recommended amounts of vitamin D supplements, poor status persists in bariatric surgery patients. Studies support the use of even higher doses of vitamin D to facilitate the maintenance of normal vitamin D status after bariatric surgery [27, 33, 38-41]. Previous studies demonstrated that cholecalciferol may provide a fast and larger increase in serum $25(\mathrm{OH}) \mathrm{D}$ than ergocalciferol [42-45]. At the inception of this study, however, the only high dose vitamin D supplement was ergocalciferol. Specific aims of the study were to determine if serum $25(\mathrm{OH}) \mathrm{D}$ levels are improved by the consumption of a monthly ergocalciferol supplement (average daily dose of 3333 IUs of vitamin $\mathrm{D}$ ) by subjects after bariatric surgery and to determine if it sustains an increase in serum $25(\mathrm{OH})$ D levels to normal range $(30-100 \mathrm{ng} / \mathrm{mL})$ in bariatric surgery patients.

\section{Material and methods}

\section{Participants}

This study involved thirty-two patients (22 control group; 10 experimental group) having elective gastric bypass or biliopancreatic diversion with duodenal switch surgery for severe obesity. Subjects were alternately divided into a control group receiving the standard level vitamin D supplement in the surgery center's protocol and a vitamin D supplement (experimental) group receiving an additional monthly dose of 100,000 IUs of ergocalciferol. It was not intended to have an unbalanced study design with only 10 subjects in the experimental group. Initially, there were 39 subjects assigned to each group. The control group had 12 non-white subjects and the experimental group had 6 non-white subjects. At-test indicated no significant difference between the control and experimental groups' $25(\mathrm{OH})$ D mean levels $(p<0.16)$ at baseline. Please see Figure 1 showing the decreased number of participants over time and reason for exclusion. In the control group, 14 subjects had the Roux-En-Y gastric bypass (RYGB), and eight subjects had the biliopancreatic diversion with duodenal switch (DS) surgery. In the experimental group, eight subjects had the RYGB and two subjects had the DS surgery.

The study was approved by the ethical committee of Texas Tech University Institutional Review Board for the protection of human subjects. All subjects signed informed consent prior to participating in the study. Subjects were recruited and along with their baseline lab values (serum $25(\mathrm{OH}) \mathrm{D}$, calcium, and hemoglobin A1c) being collected, a questionnaire was completed regarding outside sources of vitamin $\mathrm{D}$, including sun exposure, multivitamins and 24-hour dietary recall. Exclusion criteria considered were age less than 18 years or greater than 70 years, serum $25(\mathrm{OH}) \mathrm{D}$ or calcium levels above the normal range at baseline prior to surgery, subjects without both pre- and postsurgery serum $25(\mathrm{OH})$ D levels, use of medications, such as steroids, cholestyramine, phenobarbital, phenytoin, and other anticonvulsant medications, and high daily sun exposure through working outdoors or regular tanning at a salon were excluded from the study.

\section{Procedure}

This research study was a prospective clinical trial of a high dose monthly ergocalciferol on vitamin D status. The control group was instructed to take the standard vitamin D and calcium supplements as prescribed, which included: a multivitamin containing 800 to $2000 \mathrm{IU}$ of cholecalciferol and 1600-2000 mg calcium citrate/1600-2000 IUs cholecalciferol in 4 daily doses. The vitamin D (experimental) group received, in addition to the control group supplements, two 50,000 IUs capsules of ergocalciferol (Drisdol) once a month. Drisdol is a prescription ergocalciferol supplements from Sanofi-Aventis US LLC. The vitamin D group was prescribed 1600-2000 IUs of vitamin D as cholecalciferol plus an additional 3333 IUs of ergocalciferol for a total daily vitamin D dose of 5733-7333 IUs per day which slightly exceeds the UL value of 4000 IUs per day [1].

Subjects who were in the vitamin D supplement (experimental) group who received the additional vitamin D supplement were asked to come to their regular follow-up appointment schedule, which was at 1 month, 3 months, 6 months, 9 months and 1 year and were given adequate amounts of vitamin D caplets to provide each subject with a total of 100,000 IUs of ergocalciferol per month. Each subject was instructed to take 2 vitamin D caplets containing 100,000 IUs ergocalciferol each month with a snack (such as 1 tablespoon of peanut butter or other food) containing some fat. They were also instructed to take the vitamin caplets 2 weeks or longer before lab work was done. 


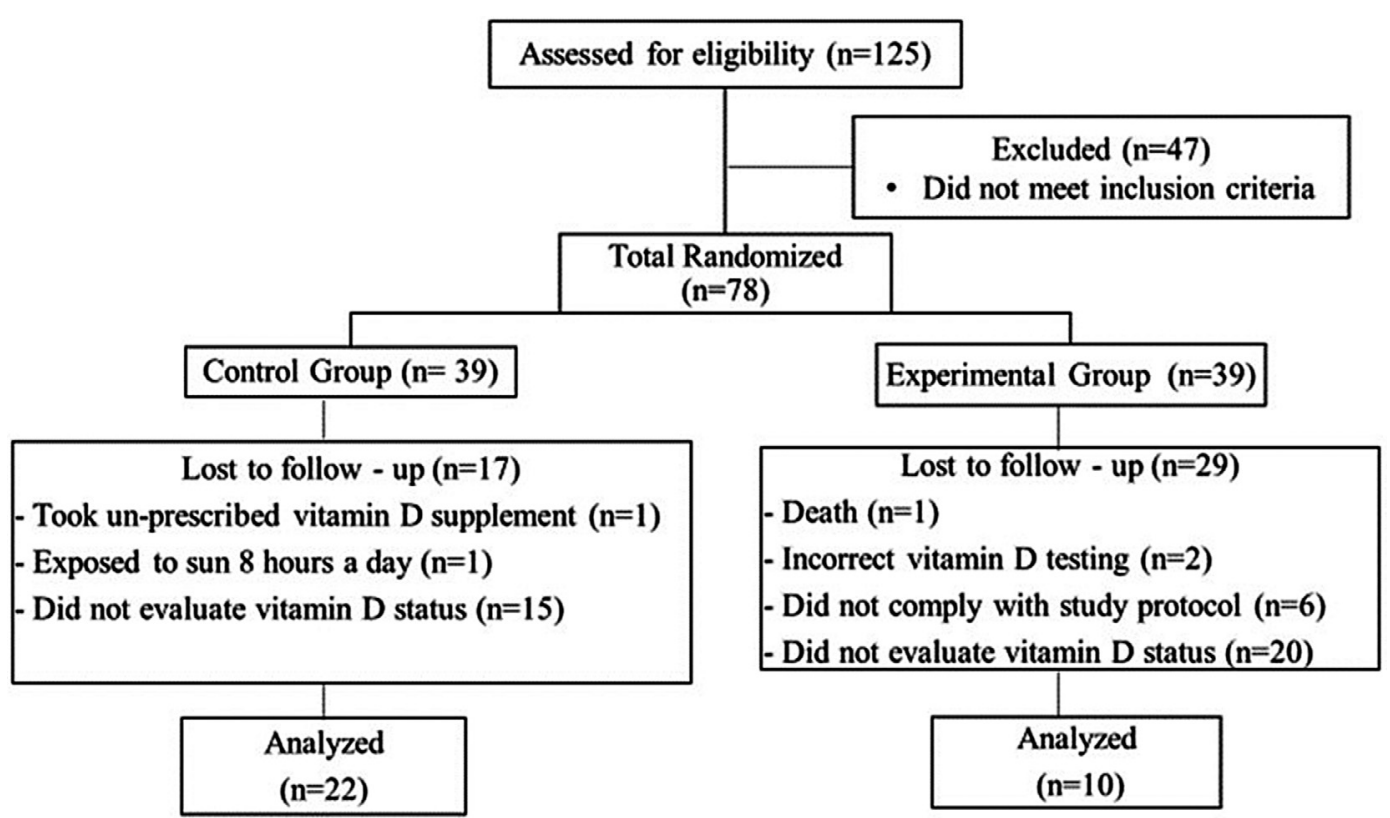

Figure 1. Study flow chart.

Subjects were called at monthly intervals and reminded to take the vitamin D caplets with the appropriate amount of fat.

Although vitamin D levels $<20 \mathrm{ng} / \mathrm{mL}$ are considered insufficient, if subjects in either group had a serum vitamin D level below the normal range $(<30 \mathrm{ng} / \mathrm{mL})$, a standard preemptive protocol for vitamin $\mathrm{D}$ deficiency was followed. During the study, recommendations were reevaluated and an additional 2000 IUs vitamin D daily was recommended if serum $25(\mathrm{OH}) \mathrm{D}$ levels fell below the normal range $(<30 \mathrm{ng} / \mathrm{mL})$. Serum $25(\mathrm{OH}) \mathrm{D}$ levels were rechecked in 3 months after recommendations were given. The assigned study intervention, follow-up, and number of participants are depicted in Figure 1. Subjects were asked for information on sun exposure, vitamins, medications, and any other supplement usage before each blood sample was taken.

\section{Lab methods}

The subjects had blood analyses (such as $25(\mathrm{OH}) \mathrm{D}$, calcium, and hemoglobin A1c) that were completed on every patient before and one year after surgery to assess response to the vitamin D protocol in this study. Form of vitamin D analyzed was total $25(\mathrm{OH}) \mathrm{D}$ and methods used for analyses were Liquid Chromatography with tandem mass spectrometry (LC-MS-MS), which is a powerful analytical technique that combines the separating power of liquid chromatography with the highly sensitive and selective mass analysis capability of triple quadrupole mass spectrometry. Samples are pumped through a stationary phase (LC column) by a mobile phase flowing through at high pressure. After elution from the LC column, the effluent is directed to the mass spectrometer. This is a fast, sensitive, and robust method for analysis of total $25(\mathrm{OH}) \mathrm{D}$ in serum [46]. Serum levels of $25(\mathrm{OH})$ D less than $30 \mathrm{ng} / \mathrm{mL}$ are considered insufficient in this study $[38,47,48]$. Other blood parameters related to the study such as calcium and hemoglobin A1c were included in the lab work, and the effect of the new vitamin D protocol on these parameters was assessed. Adjusted calcium values were calculated in subjects that had serum albumin levels below normal.

\section{Statistical analyses}

For each of the outcome measures, change scores from pre- to post-intervention were calculated for each individual. Descriptive statistics which include both the means and standard deviations were calculated on the study variables. Nothing suggests a significant deviation in normality, either in the probability plots or in the p-value from the Anderson-Darling test. The two-sample t-test is valid and used for change scores from pre- to postintervention.

A paired sample t-test was used to determine if there was a significant difference in mean vitamin $D$ values from preto post-supplementation. An independent sample t-test was used to assess for significant differences in group (control vs. vitamin D supplement) means as well as differences 
Table 1. Demographic and questionnaire data by study group

\begin{tabular}{|c|c|c|c|}
\hline Characteristic & $\begin{array}{l}\text { Control group } \\
\qquad N=22\end{array}$ & $\begin{array}{l}\text { Vitamin D group } \\
\qquad N=10\end{array}$ & P-value \\
\hline Age (yrs) & $33-63$ & $41-67$ & \\
\hline Mean $\pm S D$ & $48.23 \pm 10.46$ & $50.9 \pm 9.07$ & 0.492 \\
\hline Sex (\% Female) & $81.8 \%$ & $80 \%$ & 0.907 \\
\hline Race (\%) & & & $0.028 *$ \\
\hline White & $63.6 \%$ & $100 \%$ & \\
\hline Non-white & $36.4 \%$ & $0 \%$ & \\
\hline Mean Pre-surgery BMI $\left(\mathrm{kg} / \mathrm{m}^{2}\right)$ & $49.46 \pm 9.63$ & $50.63 \pm 5.9$ & 0.727 \\
\hline Surgery (\%) & & & 0.371 \\
\hline RYGB & $63.7 \%$ & $80 \%$ & \\
\hline DS & $36.4 \%$ & $20 \%$ & \\
\hline Diabetes (\%) & $50 \%$ & $30 \%$ & 0.306 \\
\hline Approximate daily sun exposure (Minutes) & $119.06 \mathrm{~min}$ & $72.5 \mathrm{~min}$ & 0.412 \\
\hline \multirow[t]{3}{*}{ Sunscreen use (\%) } & 8-Never & 2-Never & 0.684 \\
\hline & 5-Occasionally & 8-Occasionally & \\
\hline & 3-Always & & \\
\hline \multirow[t]{2}{*}{ Have tanning treatments (\%) } & Yes-2 & Yes-1 & 0.740 \\
\hline & No-20 & No-9 & \\
\hline \multirow[t]{2}{*}{ Multivitamin use } & Yes-21 & Yes-10 & 0.440 \\
\hline & No-1 & & \\
\hline \multirow[t]{2}{*}{ Calcium supplement use } & Yes-21 & Yes-10 & 0.440 \\
\hline & No-1 & & \\
\hline \multirow[t]{2}{*}{ Vitamin D supplement use } & Yes-16 & Yes-7 & 0.710 \\
\hline & No-6 & No-3 & \\
\hline \multirow[t]{2}{*}{ Other nutrient or herbal supplement use } & Yes-15 & Yes-10 & 0.134 \\
\hline & No-7 & & \\
\hline Estimated dietary vitamin $\mathrm{D}$ intake & $3.64 \mu g / d a y$ & $2.3 \mu \mathrm{g} / \mathrm{day}$ & 0.654 \\
\hline
\end{tabular}

*There was a significant difference $(p<0.05)$ among group questionnaire data; independent sample t-test.

between types of surgery, race, gender, and diabetic status. A p-value $<0.05$ was considered statistically significant. Statistical analyses were done using SPSS Version 21 (SPSS, Chicago, IL, USA) and Minitab Statistical Software: Cloud App \& Windows Desktop.

\section{Results}

\section{Demographic and baseline sun exposure, dietary vitamin $D$, and supplement use questionnaire data}

The study concluded with 32 bariatric surgery patients. Twenty-two patients (2 African Americans, 6 Hispanic, and 14 White subjects) received standard vitamin and mineral regimen (control group), while 10 patients (White subjects) received 100,000 IUs ergocalciferol each month in addition to the standard vitamin and mineral regimen (vitamin D group). Demographic and baseline data on sun exposure, dietary vitamin $\mathrm{D}$, and supplement use can be further evaluated in Table 1.

\section{Control vs. vitamin D group}

Mean changes in BMI at 1-year post-operation was $-18.12 \pm 6.46 \mathrm{~kg} / \mathrm{m}^{2}$ in the control group versus -18.84 $\pm 4.7 \mathrm{~kg} / \mathrm{m}^{2} ; \mathrm{p}=0.638$ in the vitamin $\mathrm{D}$ group. The mean changes from baseline in vitamin $\mathrm{D}$ levels at 1-year post surgery were $2.69 \pm 9.4$ and $12.4 \pm 17.0 \mathrm{ng} / \mathrm{mL}$ in control and intervention groups, respectively. The treated group showed a marginally higher mean increase in Vitamin D than the control group, $p=0.059$. Other mean changes at 1 -year post-surgery that were not significantly different include calcium $-0.264 \pm 0.45$ and $-0.21 \pm 0.509 \mathrm{mg} / \mathrm{dl}$ in control and intervention groups, respectively and $\mathrm{HbA}_{1 \mathrm{c}}-1.0 \pm 1.21$ and $-0.95 \pm 0.071 \%$ in control and intervention groups, respectively. These changes between groups can be seen in Table 2. 
Table 2. Comparing mean changes at 1-year post-operation data

\begin{tabular}{lccc}
\hline & Control group $(\mathrm{n}=22)$ & Vitamin D group $(\mathrm{n}=10)$ & \\
\cline { 2 - 3 } & Mean changes 1-year post-op & Mean changes 1-year post-op & P-value \\
\hline 25(OH)D ng/mL & $2.69 \pm 9.4$ & $12.4 \pm 17.0$ & $0.059 *$ \\
Serum Calcium mg/dl & $-0.264 \pm 0.45$ & $-0.21 \pm 0.51$ & 0.389 \\
Hemoglobin A1c \% & $-1.0 \pm 1.2$ & $-0.95 \pm 0.07$ & 0.447 \\
BMl kg/m & $-18.12 \pm 6.46$ & $-18.84 \pm 4.7$ & 0.638 \\
\hline
\end{tabular}

* Mean changes showed the treated group with a marginally higher increase for vitamin D between groups; two sample t-test. Asterisks denote marginal statistical significance $(p=0.059)$

\section{Baseline vs 1-year post-operation data}

In this study, $75 \%$ of subjects were vitamin D insufficient prior to surgery and $59 \%$ of subjects in control group remained insufficient compared to only $10 \%$ of subjects in vitamin D group after surgery. A significant increase was seen in mean serum $25(\mathrm{OH})$ D levels $(26.1 \pm 9.23$ versus $38.53 \pm 16.75 \mathrm{ng} / \mathrm{mL} ; \mathrm{p}=0.046)$ from baseline to 1 -year post-op in the vitamin $\mathrm{D}$ group receiving an additional 100,000 IUs ergocalciferol per month. There was no significant difference in the mean serum $25(\mathrm{OH}) \mathrm{D}$ levels from baseline to 1-year post-op in the control group. A significant decrease was seen in serum calcium levels in the control group. Seventeen $(77 \%)$ subjects in the control group had slight decreases in serum calcium levels; however, no subject had serum calcium out of the normal range of reference values $(8.4-11.0 \mathrm{mg} / \mathrm{dL})$. There was no significant difference among serum calcium levels in the vitamin $\mathrm{D}$ group. Both the control and vitamin D groups had significant differences in baseline and 1-year post-op hemoglobin A1c levels and BMI calculations. Differences between baseline and 1-year post-op data can be found in Figure 2.

When comparing serum $25(\mathrm{OH}) \mathrm{D}$ levels among races, the only race to compare between groups was white subjects due to the vitamin D group being 100\% Caucasian. The control group had 14 (63.6\%) white subjects. There was no significant difference between pre and 1-year post-op data in the control group $(25.67 \pm 11.79$ vs. 28.76 $\pm 7.59 \mathrm{ng} / \mathrm{mL} ; \mathrm{p}=0.316$ ). There was a significant difference between the vitamin D group subjects (26.1 \pm 9.23 vs. 38.53 $\pm 16.75 \mathrm{ng} / \mathrm{mL} ; \mathrm{p}<0.05)$. There was no significant difference between baseline mean serum $25(\mathrm{OH})$ D levels for the control group $(25.67 \pm 11.79 \mathrm{ng} / \mathrm{mL})$ compared to the vitamin $\mathrm{D}$ group $(26.1 \pm 9.23 \mathrm{ng} / \mathrm{mL} ; \mathrm{p}=0.925)$. After 1-year post-op, the vitamin D group $(38.53 \pm 16.75 \mathrm{ng} / \mathrm{mL})$ had close to a significantly higher mean serum $25(\mathrm{OH}) \mathrm{D}$ level, than the control group $(28.76 \pm 7.59 \mathrm{ng} / \mathrm{mL}) ; \mathrm{p}=0.06$.

When comparing 1-year post-operative mean serum 25 $(\mathrm{OH})$ D levels among types of surgery, there was no significant difference between RYGB $(\mathrm{n}=22)$ subjects $(30.99$ $\pm 14.47)$ and DS $(\mathrm{n}=10)$ subjects $(24.35 \pm 9.55 \mathrm{ng} / \mathrm{mL})$; $\mathrm{p}=0.19$. There was significant difference seen in mean serum $25(\mathrm{OH}) \mathrm{D}$ levels among white $24(75 \%)$ subjects $(32.83 \pm 12.91 \mathrm{ng} / \mathrm{mL})$ and non-white $8(25 \%)$ subjects $(17.18 \pm 5.62 \mathrm{ng} / \mathrm{mL}) ; \mathrm{p}<0.00$. Mean serum $25(\mathrm{OH})$ D levels did not reach significant differences between female 26 $(81.25 \%)$ subjects $(29.01 \pm 14.49)$ and male $6(18.75 \%)$ subjects $(28.52 \pm 7.42 \mathrm{ng} / \mathrm{mL}) ; \mathrm{p}=0.94$.

Serum concentrations of vitamin $\mathrm{D}$, calcium, hemoglobin A1c, and BMI measurements at baseline and 1-year post-op between groups; independent sample t-test. Values are means, with standard deviations represented by vertical bars. There was a significant difference in 1-year post-op mean serum $25(\mathrm{OH}) \mathrm{D}$ levels between the control and vitamin D group; $\mathrm{p}=0.004$. Asterisks denote statistical significance $(\mathrm{p}<0.05)$.

\section{Discussion}

Bariatric surgery patients are at an increased risk for vitamin $\mathrm{D}$ deficiency for many reasons. The majority of people with severe obesity will suffer from vitamin D deficiency due to the sequestration of vitamin $\mathrm{D}$ in the fat tissue. Furthermore, malabsorption of vitamin $\mathrm{D}$ in patients with severe obesity who undergo bariatric surgery ultimately results from impaired fat absorption [49]. This population can also have low vitamin $D$ levels because of inadequate vitamin D intake and insufficient sun exposure. A study by Carlin et al. evaluated a weekly supplement regimen in vitamin D-depleted women with extreme obesity who were randomly assigned to receive 50,000 IUs of vitamin D weekly after RYGB (group $1 ; n=30$ ) or no additional vitamin D after RYGB (group 2; n=30) [50]. All patients received a daily supplement of 800 IUs vitamin D and $1500 \mathrm{mg}$ calcium. After one year post-trial, vitamin D depletion and mean $25(\mathrm{OH}) \mathrm{D}$ level had improved significantly in group $1(14 \%$ and $37.8 \mathrm{ng} / \mathrm{mL}$, respectively) compared with the values in group $2(85 \%$ and $15.2 \mathrm{ng} / \mathrm{mL}$, respectively; $\mathrm{p}<0.00$ for both) [50]. It also showed a weekly regimen to be effective. 

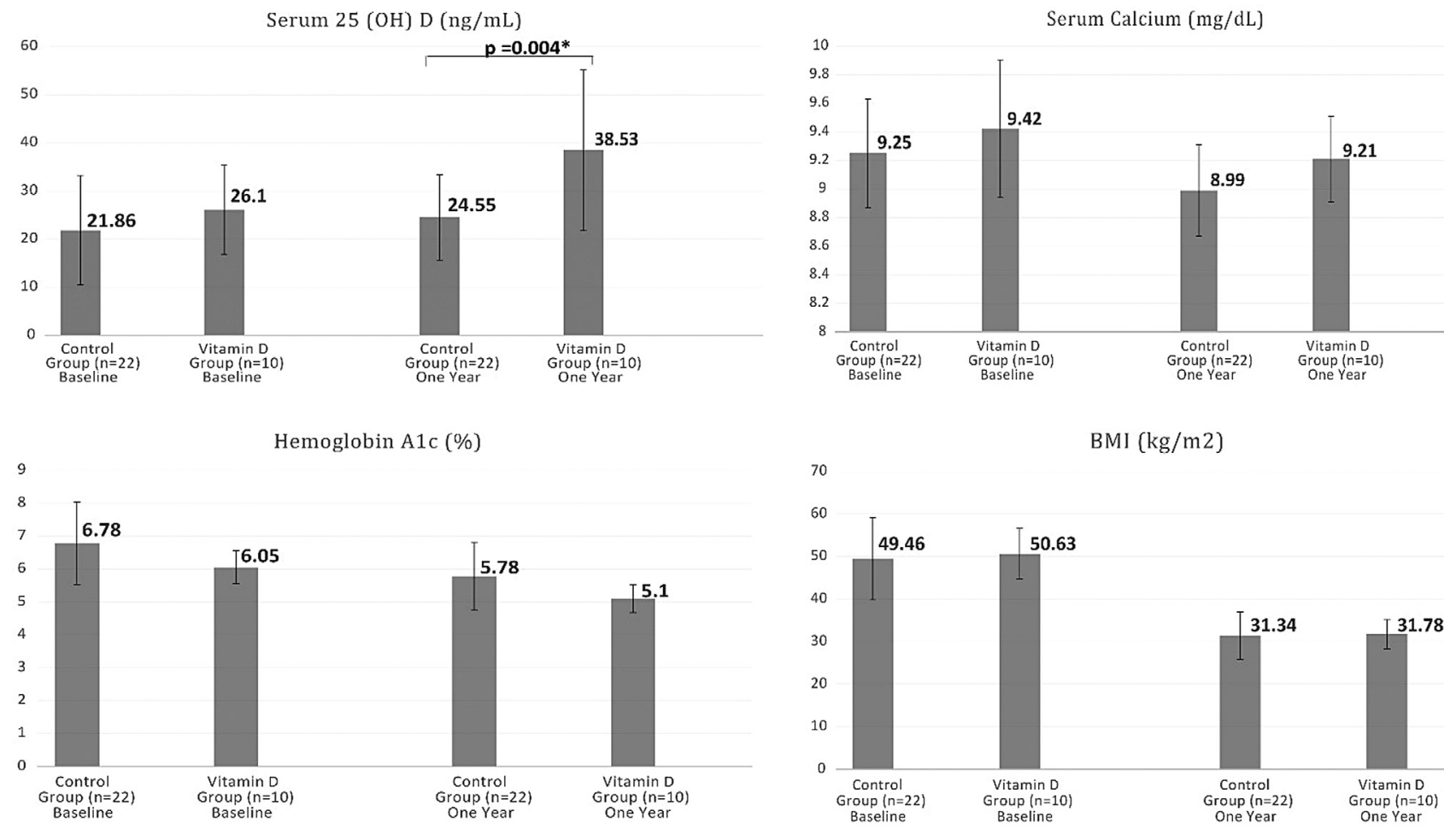

Figure 2. Baseline and 1-year post-operation values for subjects in control and vitamin D groups.

This study was designed to determine if a once monthly supplement of ergocalciferol would improve vitamin D status in RYGB and DS surgery subjects. Poor compliance in pill taking is often an obstacle in the treatment of vitamin $\mathrm{D}$ deficiency in gastric bypass and DS subjects. One barrier to successful management of less than optimal vitamin D status in bariatric surgery subjects was removed by this protocol with a once monthly versus daily supplementation regime. The current study demonstrated that bariatric surgery patients had a significant increase in serum $25(\mathrm{OH}) \mathrm{D}$ levels after receiving an additional monthly oral dose of 100,000 IUs ergocalciferol for one year post bariatric surgery.

Type 2 diabetes has a relation to low serum $25(\mathrm{OH}) \mathrm{D}$ levels [51]. Low vitamin D influences glucose intolerance, and vitamin D supplementation improves glycemia and insulin secretion in patients with type 2 diabetes [52]. Vitamin $\mathrm{D}$ has been shown to help insulin secretion in type 2 diabetics and also improves insulin sensitivity in women with gestational diabetes [53]. Some researchers state that a genetic variant of the (vitamin D receptor) VDR gene can also be a contributor to the development of type 2 diabetes [54]. In a study conducted by McGill et al. looking at how vitamin $\mathrm{D}_{3}$ was related to measures of fat mass, metabolic syndrome markers, hemoglobin A1c, and metabolic syndrome in a cross-sectional sample of 250 adults who are overweight and have obesity of different ethnicities. They found that serum vitamin $\mathrm{D}_{3}$ was inversely related to weight, BMI, and markers of type 2 diabetes (large waist, raised hemoglobin A1c) but not to adipose tissue nor to metabolic syndrome per se [55]. Ye et al. concluded from their study, investigating VDR as a candidate gene for type 2 diabetes mellitus, that VDR is not a major gene for type 2 diabetes mellitus; however, polymorphisms in the VDR gene are associated with the susceptibility to obesity in subjects with early-onset type 2 diabetes mellitus [56]. This could be a direct effect of vitamin $\mathrm{D}$ in adipocyte differentiation and metabolism or an indirect effect by modulation of insulin secretion [56]. There are many suggested reasons as to what causes vitamin D inadequacy and how it affects the prevalence of type 2 diabetes, and our study confirms this association as well. Our study was similar to Poires et al. who looked at bariatric surgery and its effect on diabetes and found $34 \%$ of subjects to be glucose impaired preoperatively and $86.5 \%$ of these subjects reverted back to euglycemia [57]. Fourteen (43.75\%) of our subjects were diabetic and $69.2 \%$ of these subjects improved to normal hemoglobin A1c.

It is imperative for patients, which have severe obesity and presenting for bariatric surgery, to have vitamin D levels assessed and started on a vitamin D supplement. However, the daily recommended amount for adults does not seem to be adequate for this patient population. Many studies demonstrate that a high dose ergocalciferol 
supplement can improve vitamin D levels. One study used different doses of vitamin D supplementation to determine how best to treat vitamin D deficiency among bariatric surgery patients. Goldner et al. evaluated three doses of cholecalciferol (800, 2,000, and 5,000 IU/day) in 45 patients undergoing Roux-en-Y gastric bypass [38]. At 12 months, the 800-, 2,000-, and 5,000-IU groups had a significantly higher mean serum $25(\mathrm{OH}) \mathrm{D}$ level than preoperatively $(\mathrm{p}=<0.001)$ and had mean $\pm \mathrm{SD}$ increase in $25(\mathrm{OH}) \mathrm{D}$ of $27.5 \pm 40.0$ (11 \pm 16$), 60.2 \pm 37.4(24.08$ $\pm 14.96)$, and $66.1 \pm 42.2 \mathrm{nmol} / \mathrm{L}(26.44 \pm 16.88 \mathrm{ng} / \mathrm{mL})$, respectively [38]. The end values were $75.3 \pm 64.8$ (30.1 \pm 25.9), $97.7 \pm 60.7$ (39.08 \pm 24.26$), 123.4 \pm 68 \mathrm{nmol} / \mathrm{L}(49.34 \pm$ $27.18 \mathrm{ng} / \mathrm{mL}$ ), respectively. At the end of the current study, the mean serum $25(\mathrm{OH})$ D was significantly higher $(\mathrm{p}=0.046)$ in subjects that received the additional monthly 100,000 IUs ergocalciferol than in subjects that received the standard regimen with a mean increase of $12.43 \pm$ $7.52 \mathrm{ng} / \mathrm{mL}$ and $70 \%$ of subjects improving serum $25(\mathrm{OH}) \mathrm{D}$ levels greater than $30 \mathrm{ng} / \mathrm{mL}$. Our results were similar to Goldner et al. dose of 2,000 IUs cholecalciferol as our mean end value was $38.53 \pm 16.75 \mathrm{ng} / \mathrm{mL}$ [38]. We also had similarities with the 2,000 and 5,000 IUs cholecalciferol in \% of improvement of vitamin D level, as Goldner et al. showed $44 \%, 78 \%$, and $70 \%$ that achieved $25(\mathrm{OH})$ D levels $\geq 75 \mathrm{nmol} / \mathrm{L}(\geq 30 \mathrm{ng} / \mathrm{mL})(\mathrm{p}=0.38)$ after receiving $800,2,000$, and 5,000 IUs cholecalciferol daily for one year, respectively [38]. Our daily dose of vitamin D averaged 3333 IU of ergocalciferol. Our results were less significant than Goldner et al.; this could be due to the use of cholecalciferol, which is shown to be better absorbed. In addition, one group received a slightly higher dose in one arm of their study than the current study.

Interestingly, our findings were similar to another study conducted by Carlin et al. where 60 vitamin D-depleted women with severe obesity received 50,000 IU of ergocalciferol weekly after RYGB (group $1 ; n=30$ ) or no additional vitamin D after RYGB (group 2; $n=30$ ) [50]. All patients received a daily supplement of 800 IU vitamin D and $1500 \mathrm{mg}$ calcium. The serum $25(\mathrm{OH}) \mathrm{D}$ was measured preoperatively and one year after RYGB and the mean $25(\mathrm{OH})$ D level significantly improved in group $1(37.8 \mathrm{ng} / \mathrm{mL}) \mathrm{com}$ pared with the values in group $2(15.2 \mathrm{ng} / \mathrm{mL} ; \mathrm{p}<0.05)$ [50]. The significance was greater in Carlin et al. study, which is very likely due to their 50,000 IUs weekly dose $(200,000$ IUs monthly), compared to our 100,000 IUs monthly dose. Furthermore, their subjects had a lower baseline mean serum $25(\mathrm{OH})$ D level than our study. However, our 1-year post-op mean serum $25(\mathrm{OH})$ D levels were very similar.

There were limitations to this study that included a small sample size and unequal distribution of race. This study depended on subjects completing the study, and many subjects had to be withdrawn due to noncompliance with the study protocol. In addition, this study was not able to include additional laboratory tests to rule out vitamin D toxicity. However, there were no subjects that exhibited signs or symptoms of vitamin D toxicity or hypercalcemia. The highest serum $25(\mathrm{OH})$ D level in the study was $80.1 \mathrm{ng} / \mathrm{mL}$ so no subjects had elevated serum vitamin D levels in the vitamin D supplemented group. It should also be noted that vitamin $\mathrm{D}$ is not the only micronutrient deficiency risk among bariatric surgery patients. There are risks of other micronutrient deficiencies, including vitamins B12, thiamine, folate, $\mathrm{A}$, and $\mathrm{K}$, along with the trace minerals iron, zinc, and copper. Nutritional complications after bariatric surgery need to be monitored and further investigated.

\section{Conclusion}

In conclusion, this study demonstrates that bariatric surgery subjects have inadequate serum $25(\mathrm{OH}) \mathrm{D}$ levels prior to having surgery. The results indicated that a once monthly high dose ergocalciferol supplement, though marginal, will increase serum $25(\mathrm{OH}) \mathrm{D}$ in the experimental group that was treated after one year. The findings of this study showed 100,000 IUs ergocalciferol once a month is a safe and effective treatment for vitamin D deficiency and insufficiency in most patients having bariatric surgery. The results of this study focus on the advantageous effect of vitamin D supplementation in bariatric surgery patients. With further research, better treatment regimens can be found to help the bariatric surgery patients with compliancy in their vitamin/mineral supplementation and improve vitamin/mineral deficiencies and insufficiencies. Furthermore, more research is needed to find the optimal dose of vitamin $\mathrm{D}$ to prevent and treat vitamin inadequacies in the bariatric surgery population.

\section{References}

1. National Institutes of Health (Office of Dietary Supplements). Dietary Supplement Fact Sheet: Vitamin DAvailable from https://ods.od.nih.gov/factsheets/VitaminD-HealthProfessional/ \#en62

2. Walsh JS, Bowles S, Evans AL. Vitamin D in obesity. Curr Opin Endocrinol Diabetes Obes. 2017;24(6):389-94.

3. Borges JLC, Miranda ISM, Sarquis MMS, Borba V, Maeda SS, Lazaretti-Castro $M$, et al. Obesity, Bariatric Surgery, and Vitamin D. J Clin Densitom. 2018;21(2):157-62.

4. Peterson LA, Cheskin LJ, Schweitzer MA, Magnuson TH, Steele KE. Treatment for vitamin D deficiency prior to bariatric surgery: a prospective cohort study. Obes Surg. 2016;26(5): 1146-9.

5. Buffington C, Walker B, Cowan GS, Scruggs D. Vitamin D deficiency in the morbidly obese. Obes Surg. 1993;3(4):421-4. 
6. Zakharova I, Klimov L, Kuryaninova V, Nikitina I, Malyavskaya S, Dolbnya $S$, et al. Vitamin D insufficiency in overweight and obese children and adolescents. Front. Endocrinol. 2019;10: 103.

7. Vimaleswaran KS, Berry DJ, Lu C, Tikkanen E, Pilz S, Hiraki LT, et al. Causal relationship between obesity and vitamin $D$ status: bi-directional Mendelian randomization analysis of multiple cohorts. PLoS Med. 2013;10(2):e1001383.

8. Ekwaru JP, Zwicker JD, Holick MF, Giovannucci E, Veugelers PJ. The importance of body weight for the dose response relationship of oral vitamin D supplementation and serum 25hydroxyvitamin D in healthy volunteers. PLoS One. 2014;9(11): e111265.

9. Veugelers PJ, Pham TM, Ekwaru JP. Optimal vitamin D supplementation doses that minimize the risk for both low and high serum 25-hydroxyvitamin D concentrations in the general population. Nutrients. 2015;7(12):10189-208.

10. Mahlay NF, Verka LG, Thomsen K, Merugu S, Salomone M. Vitamin D status before Roux-en-Y and efficacy of prophylactic and therapeutic doses of vitamin $D$ in patients after Roux-en-Y gastric bypass surgery. Obes Surg. 2009;19(5): 590-4.

11. Ernst B, Thurnheer M, Schmid SM, Wilms B, Schultes B. Seasonal variation in the deficiency of 25-hydroxyvitamin $D(3)$ in mildly to extremely obese subjects. Obes Surg. 2009;19(2): 180-3.

12. Wortsman J, Matsuoka LY, Chen TC, Lu Z, Holick MF. Decreased bioavailability of vitamin $\mathrm{D}$ in obesity. Am J Clin Nutr. 2000;72(3):690-3.

13. Harris SS, Dawson-Hughes B. Reduced sun exposure does not explain the inverse association of 25-hydroxyvitamin D with percent body fat in older adults. JCEM. 2007;92(8):3155-7.

14. Prevention CfDCa. Adult obesity facts. Available from https:// www.cdc.gov/obesity/data/adult.html

15. Mahdy T, Atia S, Farid M, Adulatif A. Effect of Roux-en $Y$ gastric bypass on bone metabolism in patients with morbid obesity: Mansoura experiences. Obes Surg. 2008;18(12): 1526-31.

16. Shikora SA, Kim JJ, Tarnoff ME. Nutrition and gastrointestinal complications of bariatric surgery. Nutr Clin Pract. 2007;22(1): 29-40.

17. Salameh JR. Bariatric surgery: past and present. Am J Med Sci. 2006;331(4):194-200.

18. Corbeels K, Verlinden L, Lannoo M, Simoens C, Matthys C, Verstuyf $A$, et al. Thin bones: Vitamin D and calcium handling after bariatric surgery. Bone Rep. 2018;8:57-63.

19. Arias PM, Domeniconi EA, García M, Esquivel CM, Martínez Lascano F, Foscarini JM. Micronutrient deficiencies after roux-en-y gastric bypass: long-term results. Obes Surg. 2020;30(1):169-73.

20. Homan J, Betzel B, Aarts EO, Dogan K, van Laarhoven KJ, Janssen IM, et al. Vitamin and mineral deficiencies after biliopancreatic diversion and biliopancreatic diversion with duodenal switch-the rule rather than the exception. Obes Surg. 2015;25(9):1626-32.

21. Homan J, Schijns W, Aarts EO, Janssen IMC, Berends FJ, de Boer $\mathrm{H}$. Treatment of vitamin and mineral deficiencies after biliopancreatic diversion with or without duodenal switch: a major challenge. Obes Surg. 2018;28(1):234-41.

22. Nett $P$, Borbély $Y$, Kröll D. Micronutrient supplementation after biliopancreatic diversion with duodenal switch in the long term. Obes Surg. 2016;26(10):2469-74.

23. Mangan A, Le Roux CW, Miller NG, Docherty NG. Iron and vitamin D/calcium deficiency after gastric bypass: mechanisms involved and strategies to improve oral supplement disposition. Curr Drug Metab. 2019;20(3):244-52.
24. Dogan K, Homan J, Aarts EO, de Boer H, van Laarhoven C, Berends FJ. Long-term nutritional status in patients following Roux-en-Y gastric bypass surgery. Clin Nutr. 2018;37(2): 612-7.

25. James H, Lorentz P, Collazo-Clavell ML. Patient-reported adherence to empiric vitamin/mineral supplementation and related nutrient deficiencies after roux-en-y gastric bypass. Obes Surg. 2016;26(11):2661-6.

26. Martínez-Ortega AJ, Olveira G, Pereira-Cunill JL, ArraizaIrigoyen C, García-Almeida JM, Irles Rocamora JA, et al. Recommendations based on evidence by the Andalusian Group for Nutrition Reflection and Investigation (GARIN) for the pre- and postoperative management of patients undergoing obesity surgery. Nutrients. 2020;12(7).

27. Chakhtoura MT, Nakhoul NN, Shawwa K, Mantzoros C, El Haj. Fuleihan GA. Hypovitaminosis D in bariatric surgery: A systematic review of observational studies. Metabolism. 2016;65(4):574-85

28. Hewitt S, Søvik TT, Aasheim ET, Kristinsson J, Jahnsen J, Birketvedt GS, et al. Secondary hyperparathyroidism, vitamin D sufficiency, and serum calcium 5 years after gastric bypass and duodenal switch. Obes Surg. 2013;23(3):384-90.

29. Lespessailles E, Toumi H. Vitamin D alteration associated with obesity and bariatric surgery. Exp Biol Med (Maywood). 2017;242(10):1086-94.

30. Newbury L, Dolan K, Hatzifotis M, Low N, Fielding G. Calcium and vitamin $\mathrm{D}$ depletion and elevated parathyroid hormone following biliopancreatic diversion. Obes Surg. 2003;13(6): 893-5.

31. Slater GH, Ren CJ, Siegel N, Williams T, Barr D, Wolfe B, et al. Serum fat-soluble vitamin deficiency and abnormal calcium metabolism after malabsorptive bariatric surgery. J Gastrointest Surg. 2004;8(1):48-55. discussion 4-5.

32. Fox A, Slater C, Ahmed B, Ammori BJ, Senapati S, Akhtar K, et al. Vitamin $D$ status after gastric bypass or sleeve gastrectomy over 4 years of follow-up. Obes Surg. 2020;30(4): 1473-81.

33. Carlin AM, Rao DS, Yager KM, Genaw JA, Parikh NJ, Szymanski W. Effect of gastric bypass surgery on vitamin D nutritional status. Surg Obes Relat Dis. 2006;2(6):638-42.

34. Rousseau C, Jean S, Gamache P, Lebel S, Mac-Way F, Biertho $L$, et al. Change in fracture risk and fracture pattern after bariatric surgery: nested case-control study. BMJ. 2016;354:i3794.

35. Nakamura KM, Haglind EG, Clowes JA, Achenbach SJ, Atkinson EJ, Melton LJ 3rd, et al. Fracture risk following bariatric surgery: a population-based study. Osteoporos Int. 2014;25(1):151-8.

36. Gagnon C, Schafer AL. Bone health after bariatric surgery. JBMR Plus. 2018;2(3):121-33.

37. Yu EW, Bouxsein ML, Putman MS, Monis EL, Roy AE, Pratt JS, et al. Two-year changes in bone density after Roux-en-Y gastric bypass surgery. J Clin Endocrinol Metab. 2015;100(4): 1452-9.

38. Goldner WS, Stoner JA, Lyden E, Thompson J, Taylor K, Larson $L$, et al. Finding the optimal dose of vitamin $D$ following Roux-en-Y gastric bypass: a prospective, randomized pilot clinical trial. Obes Surg. 2009;19(2):173-9.

39. Topart P, Becouarn G, Sallé A, Ritz P. Biliopancreatic diversion requires multiple vitamin and micronutrient adjustments within 2 years of surgery. Surg Obes Relat Dis. 2014;10(5): 936-41.

40. Lanzarini E, Nogués X, Goday A, Benaiges D, de Ramón M, Villatoro $\mathrm{M}$, et al. High-dose vitamin d supplementation is necessary after bariatric surgery: a prospective 2-year followup study. Obes Surg. 2015;25(9):1633-8. 
41. da Rosa CL, Dames Olivieri Saubermann AP, Jacqueline J, Pereira SE, Saboya C, Ramalho A. Routine supplementation does not warrant the nutritional status of vitamin $D$ adequate after gastric bypass Roux-en-Y. Nutr Hosp. 2013;28(1): 169-72.

42. Heaney RP, Recker RR, Grote J, Horst RL, Armas LA. Vitamin D (3) is more potent than vitamin $\mathrm{D}(2)$ in humans. J Clin Endocrinol Metab. 2011;96(3):E447-52.

43. Trang HM, Cole DE, Rubin LA, Pierratos A, Siu S, Vieth R. Evidence that vitamin D3 increases serum 25-hydroxyvitamin D more efficiently than does vitamin D2. Am J Clin Nutr. 1998;68(4):854-8.

44. Armas LA, Hollis BW, Heaney RP. Vitamin D2 is much less effective than vitamin D3 in humans. J Clin Endocrinol Metab. 2004;89(11):5387-91.

45. Glendenning P, Chew GT, Seymour HM, Gillett MJ, Goldswain PR, Inderjeeth CA, et al. Serum 25-hydroxyvitamin D levels in vitamin D-insufficient hip fracture patients after supplementation with ergocalciferol and cholecalciferol. Bone. 2009; 45(5):870-5.

46. Maunsell Z, Wright DJ, Rainbow SJ. Routine isotope-dilution liquid chromatography-tandem mass spectrometry assay for simultaneous measurement of the 25-hydroxy metabolites of vitamins D2 and D3. Clin Chem. 2005;51(9):1683-90.

47. Moyad MA. Vitamin D: a rapid review. Dermatol Nurs. 2009; 21(1):25-30.

48. Wang TJ, Pencina MJ, Booth SL, Jacques PF, Ingelsson E, Lanier K, et al. Vitamin D deficiency and risk of cardiovascular disease. Circulation. 2008;117(4):503-11.

49. Jin J, Robinson AV, Hallowell PT, Jasper JJ, Stellato TA, Wilhem SM. Increases in parathyroid hormone (PTH) after gastric bypass surgery appear to be of a secondary nature. Surgery. 2007;142(6):914-20; discussion -20.

50. Carlin AM, Rao DS, Yager KM, Parikh NJ, Kapke A. Treatment of vitamin $D$ depletion after Roux-en-Y gastric bypass: a randomized prospective clinical trial. Surg Obes Relat Dis. 2009;5(4):444-9.

51. Berridge MJ. Vitamin D deficiency and diabetes. Biochem J. 2017;474(8):1321-32.

52. Chiu KC, Chu A, Go VL, Saad MF. Hypovitaminosis D is associated with insulin resistance and beta cell dysfunction. Am J Clin Nutr. 2004;79(5):820-5.

53. Shahgheibi S, Farhadifar F, Pouya B. The effect of vitamin D supplementation on gestational diabetes in high-risk women: Results from a randomized placebo-controlled trial. J Res Med Sci. 2016;21:2.

54. Ferrarezi DA, Bellili-Muñoz N, Dubois-Laforgue D, Cheurfa N, Lamri $A$, Reis $A F$, et al. Allelic variations of the vitamin $D$ receptor (VDR) gene are associated with increased risk of coronary artery disease in type 2 diabetics: the DIABHYCAR prospective study. Diabetes Metab. 2013;39(3):263-70.

55. McGill AT, Stewart JM, Lithander FE, Strik CM, Poppitt SD. Relationships of low serum vitamin D3 with anthropometry and markers of the metabolic syndrome and diabetes in overweight and obesity. Nutr J. 2008;7:4.

56. Ye WZ, Reis AF, Dubois-Laforgue D, Bellanné-Chantelot C, Timsit J, Velho G. Vitamin D receptor gene polymorphisms are associated with obesity in type 2 diabetic subjects with early age of onset. Eur J Endocrinol. 2001;145(2):181-6.

57. Pories WJ, MacDonald KG, Morgan EJ, Sinha MK, Dohm GL, Swanson MS, et al. Surgical treatment of obesity and its effect on diabetes: 10-y follow-up. Am J Clin Nutr. 1992;55(2 Suppl): 582S-5S.

\section{History}

Received February 8, 2021

Accepted August 20, 2021

Published online September 15, 2021

\section{Acknowledgement}

The authors are thankful to Bayer HealthCare LLC Consumer Care for donating Drisdol ergocalciferol supplement.

\section{Conflict of interest}

The authors declare that there are no conflicts of interest.

\section{Author's contribution}

Study conception and design: S. Galyean, D. Syn, and M. Boylan; data collection: S. Galyean, D. Syn, and M. Boylan; analysis and interpretation of results: S. Galyean and M. Boylan; draft manuscript preparation: S. Galyean, D. Syn, H. Subih, and M. Boylan. All authors reviewed the results and approved the final version of the manuscript.

\section{ORCID}

Shannon Galyean

(D) https://orcid.org/0000-0002-9757-0039

\section{Shannon Galyean, PhD, RDN, LD}

Texas Tech University

1301 Akron Ave

Lubbock, TX 79409

USA

shannon.galyean@ttu.edu 